\title{
IMPLEMENTASI POROS MARITIM DALAM PRESPEKTIF KEBIJAKAN
}

\author{
(Maritime Axis in the Perspective of Policy Making)
}

\author{
Muhar Junef \\ Pusat Penelitian dan Pengembangan Hukum \\ Badan penelitian dan Pengembangan Hukum dan Hak Asasi Manusia \\ Jalan HR Rasuna Said Kavling 4-5 Kuningan Jakarta Selatan 12940 \\ Telp. (021) 252015, Faks. (021) 2526438 \\ muharjunef@yahoo.co.id
}

\begin{abstract}
Tulisan Diterima: 11 Juni 2019; Direvisi: 4 September 2019; Disetujui Diterbitkan 10 September 2019
DOI: http://dx.doi.org/10.30641/dejure.2019.V19.303-322
\end{abstract}

\begin{abstract}
The maritime axis is now increasingly popular and has attracted the attention of many parties, including the mass media, who also often use the term in its news nowadays. The emerging term cannot be separated from the idea of the President Joko Widodo who intends to make Indonesia a global maritime axis, and also to make Indonesian waters as a world-class safe waters for all marine activities, and for such purpose the government will guarantee the security and safety of sea transportation by the people and business doers. The maritime axis cannot be developed instantly. To optimize the development at the national, regional and global levels, and especially in achieving the World Maritime Axis, require direction, orientation, strategies in anticipation of effective, consistent and sustainable development. Therefore, the researcher looks at the implementation of the Maritime Axis in the perspective of policy making. The issues on which this research is focusing are, firstly, the concept development of the world maritime axis in Indonesia, secondly, the implementation of the Indonesian maritime axis from the policy making point of view. The purpose of this study is to determine the concept development of the world maritime axis in Indonesia and its implementation. According to the results of the research, Indonesia has already implemented the concept of world maritime programs by issuing policies and their implementation; It is recommended that Indonesia must have a global maritime axis law to answer the challenges in order to materialize the Indonesian superiority. The use of this research is in order to support the creation and development of the laws and in practice as input for the stakeholders including the Government, experts, academics, practitioners and the community.
\end{abstract}

Keyword: maritime axis; policy; implementation.

\begin{abstract}
ABSTRAK
Poros maritim kini semakin populer dan menarik perhatian banyak pihak, tidak terkecuali media massa yang juga kerap memunculkan istilah tersebut dalam pemberitaannya dalam waktu-waktu belakangan ini. Mengemukanya istilah tersebut tidak terlepas dari gagasan Presiden Joko Widodo yang ingin menjadikan Indonesia sebagai poros maritim dunia, juga ingin menjadikan wilayah perairan Indonesia sebagai wilayah perairan yang aman di dunia bagi semua aktivitas laut, dan untuk itu pemerintah akan menjamin keamanan dan keselamatan transportasi laut yang dilakukan oleh masyarakat maupun pelaku usaha. Pembangunan maritim tidak bisa dilakukan serba instan. Untuk mengoptimalkan pembangunan maritim di tingkat nasional, regional dan global, dan khususnya dalam mencapai poros maritim dunia dibutuhkan arah, orientasi, strategi dan antisipasi pembangunan yang efektif, konsisten dan berkelanjutan. Oleh karena itu, Peneliti melihat implementasi poros maritim dalam Prespektif kebijakan. Permasalahan yang akan menjadi fokus dalam penelitian ini adalah pertama bagaimana perkembangan konsep poros maritim dunia di Indonesia, kedua
\end{abstract}


bagaimana implementasi poros maritim Indonesia dari prespektif kebijakan. Adapun tujuan penelitian ini adalah untuk mengetahui perkembangan konsep poros maritim dunia di Indonesia dan implementasinya. Berdasarkan hasil penelitian bahwa Indonesia sudah menerapkan konsep proros maritim dunia dengan mengeluarkan kebijakan dan implementasinya; disarankan Indonesia mempunyai undang-undang poros maritim dunia untuk menjawab tantangan demi mewujudkan keunggulan Indonesia. Adapun kegunaan dari penelitian ini adalah dalam rangka mendukung pembentukan dan pengembangan hukum dan secara praktis sebagai bahan masukan bagi para pemangku kepentingan antara lain Pemerintah, para ahli, akademisi, praktisi dan masyarakat.

Kata kunci: poros maritim; kebijakan; implementasi.

\section{PENDAHULUAN}

Negara Indonesia merupakan negara kepulauan yang dua pertiga wilayahnya terdiri atas lautan dan kaya akan sumberdaya alam laut. Indonesia sebagai negara kepulauan yang terbesar di dunia yang terdiri dari 17.499 pulau dari Sabang hingga Merauke. Luas total wilayah Indonesia adalah 7, 81 juta km2 yang terdiri dari 2,01 juta $\mathrm{km} 2$ daratan, 3,25 juta km2 lautan, dan 2,55 juta km2 Zona Ekonomi Eksklusif (ZEE). ${ }^{1}$ Adapun garis pantai sepanjang $95.181 \mathrm{~km} 2$ dan terletak pada posisi sangat strategis antara benua Asia dan Benua Australia serta Samudera Hindia dan Pasifik. Sebagai negara kepulauan yang memiliki laut yang luas dan garis pantai yang panjang, sektor maritim dan kelautan menjadi sangat strategis bagi Indonesia ditinjau dari aspek ideologi, politik, ekonomi, sosial budaya, hukum, lingkungan, pertahanan, dan keamanan. ${ }^{2}$

Pemerintahan Presiden Joko Widodo mengembalikan semangat maritim dengan menjadikan Indonesia sebagai poros maritim dunia. Poros maritim dunia pun muncul dan dikampanyekan sebagai kebijakan pemerintahan, dengan menjadikan sektor maritim sebagai pendulum, panduan, atau penentu, sekaligus tujuan pembangunan kabinet kerjanya. Hal dapat dikatakan, pencapaian sembilan agenda kerja pemerintahannya (Nawacita) terkait dengan implementasi pentingnya sektor maritim bagi Republik Indonesia, untuk mencapai tujuan negara, baik dalam jangka pendek, menengah, maupun

1 Muhar Junef, "Penegakan Hukum Dalam Rangka Penataan Ruang Guna Mewujudkan Pembangunan Berkelanjutan," Penelitian Hukum De Jure 17, no. 4 (2017): 379-391. Jakarta. 2017.

2 Safril Hidayat dan Ridwan, "Kebijakan Poros Maritim Dan Keamanan Nasional Indonesia: Tantangan Dan Harapan," Jurnal Pertahanan \& Bela Negara 7, no. 3 (2017): 108-121. panjang. Artinya Nawacita atau 9 (sembilan) program, yang menjadi tujuan Pemerintahan Joko Widodo, terutama, tujuan pertama dan ketiga, yakni,"Menghadirkan kembali negara untuk melindungi segenap bangsa dan memberikan rasa aman pada seluruh warga negara, melalui politik luar negeri bebas-aktif, keamanan nasional yang terpercaya dan pembangunan pertahanan negara Tri Matra terpadu yang dilandasi kepentingan nasional dan memperkuat jati diri sebagai negara maritim" dan "Membangun Indonesia dari pinggiran dengan memperkuat daerah-daerah dan desa dalam kerangka negara kesatuan. Kemudian dari Nawacita, para menteri kabinet Joko Widodo menurunkan berbagai kebijakan pemerintah dalam program-program aksi mereka di tingkat yang lebih rendah dan realistis. Kebijakan dan program aksi yang lebih jelas tampak dari apa yang dilakukan oleh Kementeri Kelautan dan Perikanan (KKP), Susi Pudjiastuti, dengan jajaran kementeriannya. Langkahnya kemudian diikuti oleh pemangku kepentingan lainnya di pemerintahan, terutama TNI AL.

Selanjutnya pada konsep Poros Maritim Dunia dituangkan dalam Peraturan Presiden Nomor 2 Tahun 2015 tentang Rencana Pembangunan Jangka Menengah Nasional (RPJMN) 2015-2019. Indonesia sebagai poros maritim dunia ditopang dengan lima pilar utama yaitu: pertama, pembangunan kembali budaya maritim Indonesia; kedua, komitmen menjaga dan mengelola sumber daya laut dengan fokus membangun kedaulatan pangan laut melalui pengembangan industri perikanan dengan menempatkan nelayan sebagai pilar utama; ketiga, komitmen mendorong pengembangan infrastruktur dan konektivitas maritim dengan membangun tol laut, pelabuhan laut, logistik, dan industri perkapalan, serta pariwisata maritim; keempat, diplomasi maritim yang mengajak semua mitra Indonesia untuk bekerja sama pada bidang 
kelautan; dan kelima, membangun kekuatan pertahanan maritim. ${ }^{3}$

Dengan lima pilar tersebut maka yang dimaksud dengan poros maritim dunia adalah menjadikan Indonesia sebagai negara maritim yang besar, kuat, dan makmur melalui pengembalian identitas Indonesia sebagai bangsa maritim, pengamanan kepentingan dan keamanan maritim, pemberdayaan seluruh potensi maritim demi kemakmuran bangsa, pemerataan ekonomi Indonesia melalui tol laut, dan melaksanakan diplomasi maritim dalam politik luar negeri Indonesia lima tahun kedepan. ${ }^{4}$

Posisi strategis Indonesia dengan poros maritim dunia dalam perdagangan internasional adalah bahwa posisi strategis Negara Kesatuan Republik Indonesia diantara persilangan samudra Hindia dan samudra Pasifik secara otomatis memberikan banyak potensi sumber daya ekonomi laut yang bisa dikelola dan dimanfaatkan untuk masa depan bangsa dan tulang punggung pembangunan nasional, namun pemanfaatan potensi sumber daya laut secara optimal haruslah diarahkan pada pendayagunaan sumber daya ikan dengan memperhatikan daya dukung yang ada dan kelestariannya guna meningkatkan kesejahteraan rakyat. $^{5}$

Istilah "poros maritim" kini semakin populer dan menarik perhatian banyak pihak, tidak terkecuali media massa yang juga kerap memunculkan istilah tersebut dalam pemberitaannya dalam waktu- waktu belakangan ini. Mengemukanya istilah tersebut tidak terlepas dari gagasan Presiden Joko Widodo (Jokowi) yang ingin menjadikan Indonesia sebagai poros maritim dunia. Menurut Presiden RI ke-7 tersebut, sebagaimana dikemukakan dalam pidatonya seusai pelantikan di hadapan Majelis Permusyawaratan Rakyat (MPR), 20 Oktober 2014, "kita telah terlalu lama memunggungi laut, memunggungi samudera, dan memunggungi selat dan teluk, dan kini saatnya kita mengembalikan semuanya sehingga "Jalesveva Jayamahe", di laut justru kita jaya, sebagaimana semboyan kita di masa lalu, bisa kembali". 6

\footnotetext{
Ibid.

Dewan Kelautan Indonesia (2012).

Peraturan Menteri Perhubungan Nomor 68 Tahun 2011 Tentang Alur Pelayaran Di Laut.,

6 Muahamad. Victor Simela. 2014. Indonesia Mепијu Poros Maritim Dunia, "Info Singkat Hubungan Internasional, Vol. VI, No. 21,(November 2014).
}

Mengacu kepada keterangan Kepala Badan Perencanaan Pembangunan Nasional (Bappenas), Andrinof Chaniago, dikatakannya bahwa Jokowi ingin menjadikan wilayah perairan Indonesia sebagai wilayah perairan yang paling aman di dunia bagi semua aktivitas laut, dan untuk itu pemerintah akan menjamin keamanan dan keselamatan transportasi laut yang dilakukan oleh masyarakat maupun pelaku usaha. Untuk itu pula, semua jajaran kementerian Kabinet Kerja Jokowi pun diminta mendukung upaya pemerintah menjadikan Indonesia sebagai poros maritim dunia. Dalam konferensi pers pertama di kantor kementerian luar negeri, 29 Oktober 2014, Menteri Luar Negeri Retno LP Marsudi menyatakan siap untuk menjadikan Indonesia sebagai poros maritim dunia dan akan mempromosikannya di fora internasional, seperti di KTT APEC, KTT ASEAN, dan G-20 pada bulan November 2014 yang dihadiri oleh Indonesia. ${ }^{7}$

Pentingnya peran sektor maritim untuk Indonesia, sebenarnya merupakan renaissance Negara Republik Indonesia yang secara historis pernah memiliki kejayaan maritim seperti Sriwijaya, Samudera Pasai, Ternate dan Tidore, dan sebagainya. Perkembangan semakin memburuk setelah proses penaklukan oleh kekuatan asing dari negara-negara Barat seperti Portugis, Spanyol, dan Belanda yang berakibat memudarnya perhatian sektor maritim dan pentingnya sektor darat. Hal ini terus berlangsung sampai periode kekuatan-kekuatan asing dapat diusir dari bumi nusantara. ${ }^{8}$

Pada perjuangan kontekstual kontemporer, Indonesia sebagai negara kepulauan dimulai dengan Deklarasi Djuanda pada 13 Desember 1957 sampai dengan ditetapkannya sebagai negara kepulauan (archipelagic state) dengan UNCLOS (United Nations Convention on the Law of the Sea) Tahun 1982 yang disahkan dengan Undang Undang Nomor 17 tahun 1985. Kini kebijakan poros maritim kembali mempertegas prioritas pembangunan sektor kelautan dalam pembangunan nasional. Hal ini disadari atas potensi maritim dan kelautan yang begitu besar disatu sisi merupakan berkah atas kondisi geografis Indonesia, namun disisi lainnya dapat menimbulkan konflik bila tidak dikelola dengan baik. ${ }^{9}$

\footnotetext{
7 Ibid, hal.6.

8 Safril Hidayat dan Ridwan, "Kebijakan Poros Maritim Dan Keamanan Nasional Indonesia: Tantangan Dan Harapan.” ${ }^{9}$ Ibid.
} 
Posisi strategis Indonesia dengan geopolitiknya yang berada diantara dua benua dan dua samudera yang dilalui oleh ribuan kapal asing yang melintasi ALKI (Alur Laut Kepulauan Indonesia) dan selat-selat penting, disatu sisi menunjukkan strategisnya posisi geografis tersebut, namun disisi lain dapat menimbulkan kerawanan dari aspek pertahanan dan keamanan khususnya keamanan kemaritiman. Permasalahan yang dihadapi dalam aspek pertahanan dan keamanan seperti: kesadaran konsepsi wawasan nusantara yang belum dipahami sepenuhnya, keterbatasan infrastruktur dan alat utama sistem senjata, regulasi bidang kemaritiman yang belum memiliki supremasi memberikan dampak meningkatnya aktivitas ilegal menggunakan media maritim. Eksploitasi dan kegiatan ilegal terhadap sumber daya maritim dilakukan oleh aktor lokal maupun transnasional. Persoalan lainnya adalah delimitasi perbatasan maritim, kuantitas dan kualitas sumber daya manusia maritim, lemahnya penegakan hukum, dan terbatasnya infrastruktur maritim menambah daftar masalah kemaritiman di Indonesia. ${ }^{10}$

Berdasarkan uraian di atas, maka perlu dilakukan penelitian berkaitan dengan Implementasi Poros Maritim Dalam Prespektif Kebijakan. Permasalahan yang akan menjadi fokus dalam dalam penelitian ini adalah pertama bagaimana perkembangan konsep poros maritim dunia di Indonesia, kedua bagaimana implementasi poros maritim Indonesia dari prespektif kebijakan. Adapun tujuan penelitian ini adalah untuk mengetahui perkembangan konsep poros maritim dunia di Indonesia dan implementasinya dari prespektif kebijakan. Adapun kegunaan dari penelitian ini adalah dalam rangka mendukung pembentukan dan pengembangan hukum dan secara praktis sebagai bahan masukan bagi para pemangku kepentingan antara lain pemerintah, para ahli, akademisi, praktisi dan masyarakat.

\section{METODE PENELITIAN}

Metode penelitian yang digunakan dalam penelitian ini yaitu deskriptif kualitatif, penelitian ini bermaksud untuk memahami fenomena tentang apa yang dialami oleh subjek penelitian yakni implemensi kebijakan poros maritim dunia misalnya perilaku, persepsi, motivasi, tindakan, dll., secara holistic, dan dengan cara deskripsi dalam bentuk kata-kata dan bahasa, pada suatu konteks khusus yang alamiah dan dengan

\footnotetext{
${ }^{10}$ Ibid.
}

memanfaatkan berbagai metode alamiah. ${ }^{11}$ Penggunaan metode ini diharapkan dapat memberikan gambaran yang lebih mendalam dan menyeluruh mengenai realitas dan proses sosial yang akan diteliti. Serta tidak mengisolasikan individu atau organisasi kedalam variabel atau hipotesis tetapi perlu memandangnya bagian dari suatu keseluruhan.

Studi kebijakan publik pada umumnya dimaksudkan untuk menggali tindakan yang dilakukan oleh pemerintah, meliputi mengapa tindakan itu dilakukan, dengan cara dan mekanisme apa dilakukan, untuk kepentingan siapa, dan bagaimana hasil, serta dampaknya. Metode penelitian kebijakan diharapkan dapat menemukan jalan keluar yang efektif dari masalah yang ada. Dengan kata lain, metode penelitian harus memiliki relevansi terhadap masalah yang dihadapi. Implementasi kebijakan merupakan salah satu masalah kebijakan publik yang cukup penting, sehingga membutuhkan analisis yang tepat. Oleh karena itu, metode penelitian yang digunakan harus mampu menangkap fenomena yang ada dan tidak hanya sebatas angka-angka.

Sumber data yang digunakan adalah sumber data primer dan sumber data sekunder. Sumber data primer berasal dari aturan yang memiliki kekuatan hukum tetap seperti UNCLOS 1982 disahkan menjadi Undang-Undang No. 17 Tahun 1985 dan Peraturan Presiden Nomor 16 tahun 2017 tentang Kebijakan Kelautan Indonesia. Sumber data sekunder berfungsi sebagai penunjang data primer misalnya melalui buku-buku yang berkaitan dengan masalah penelitian, sumber internet yang berkaitan dengan masalah penelitian dan lain sebagainya. Jenis data yang digunakan adalah data sekunder yang diperoleh dari hasil telaah pustaka dan interpretasi dari bahan hukum yang terdapat dalam buku-buku, dokumen, akses situs serta artikel-artikel lepas. Analisis yang digunakan adalah analisis kualitatif yaitu bahan hukum yang didapat kemudian dianalisa isinya untuk mendukung permasalahan yang sedang diteliti. Teknik pengumpulan data yang dipergunakan dalam penelitian ini adalah studi kepustakaan, yaitu mengumpulkan data teori dan konsep dari perpustakaan berupa buku-buku ilmiah, buku-buku referensi dan dokumen yang ada hubungannya dengan ruang lingkup penelitian ini yang digunakan sebagai landasan pemikiran dan pembahasan serata mengumpulkan data-data dari

11 Moleong, Lexy J. 2007 : 6. Metodologi Penelitian Kualitatif. Bandung: PT. Remadja Rosdakarya. 
dokumen-dokumen yang di download dari internet sebagai bahan referensi penelitian.

\section{PEMBAHASAN DAN ANALISIS}

\section{A. Perkembangan Konsep Poros Maritim di Indonesia}

\section{Pengertian Poros Maritim Dunia}

Poros maritim merupakan sebuah gagasan strategis yang diwujudkan untuk menjamin konektifitas antar pulau, pengembangan industri perkapalan dan perikanan, perbaikan transportasi laut serta fokus pada keamanan maritim. Poros Maritim Dunia ialah menjadikan laut sebagai jalur laut. Poros Maritim Dunia bertugas untuk mengatur penyelesaian batas maritim, penataan ruang laut dan diplomasi, pengembangan industri maritim dan konektivitas laut, pengembangan industri sumber daya alam, dan jasa kelautan.

Istilah "Poros Maritim Dunia", merupakan kalimat pendek yang mengandung pengertian luas, harus dicermati, dikaji secara mendalam dan disikapi dengan bijak, waspada dan hati-hati. Istilah tersebut diantaranya dapat ditafsirkan sebagai : "Jalur Laut Maritim Dunia“, 12 artinya jalur laut yang digunakan untuk berlalu lintas oleh kapal-kapal negara-negara dunia dalam mewujudkan kepentingan nasional negaranya. Oleh karena itu, adalah tidak salah apabila negaranegara dunia akan mengambil sikap dan langkahlangkah apa saja yang diperlukan untuk melindungi, mengamankan kepentingan nasional negaranya selama melintas di jalur "Jalur Laut Maritim Dunia" tersebut. Kepentingan nasional meliputi kepentingan politik, ekonomi, sosialbudaya dan pertahanan keamanan. ${ }^{13}$

Apabila hal ini terjadi, pasti akan sangat berbahaya dan merugikan kepentingan nasional Indonesia. Sebaiknya istilah "Poros Maritim Dunia", diganti dengan istilah lain yang memberikan pengertian jelas, tidak melebar dan terukur misalnya istilah : "Indonesia Pintu Dunia". Sebagai pintu dunia, maka isyarat yang disampaikan jelas bahwa Indonesia mempunyai kedaulatan dan kewenangan penuh terhadap "Jalur Laut Maritim Dunia“, kewenangan menjaga pintu tersebut, kewenangan kapan pintu harus dibuka dan kapan harus ditutup. Pintu disini yang

12 Jalur Laut Maritim Dunia (pendapat penulis).

13 Blogspot.Com/2017/08/Pengertian-PorosMaritim.Html, Diakses Pada Hari Jumat Tanggal 15 Maret 2019 Jam 14.05 WIB. dimaksud adalah 4 (empat) selat besar yang melintasi Kepulauan Indonesia. Hal ini, sesuai UNCLOS 1982, sebagai Negara Kepulauan Indonesia diperbolehkan mengganti (menutup) ALKI (Alur Laut Kepulauan Indonesia), bila diperlukan oleh negara, dengan catatan harus menyediakan ALKI, yang lain sebagai pengganti. Dengan istilah "Indonesia Pintu Dunia", maka Indonesia mempunyai kewenangan kuat untuk mengambil langkah-langkah kebijaksanaan dalam mengelola "Jalan Laut Maritim Dunia", demi kepentingan nasional Indonesia. ${ }^{14}$ Seperti diketahui bahwa Poros Maritim Dunia adalah visi yang dicanangkan oleh Presiden Joko Widodo dalam masa kampanyenya sebagai calon presiden. Visi ini dikemukakan pertama kali pada putara ketiga debat calon presiden sekitar bulan Juli 2014. Visi ini mengasumsikan suatu kondisi di mana kekuatan geopolitik ekonomi tengah bergeser dari dunia barat ke Asia. ${ }^{15}$

Dengan demikian dapat dikatakan bahwa Indonesia memiliki peluang untuk meningkatkan posisi globalnya. ${ }^{16}$ Visi ini mengemuka di tengahtengah semakin menguatnya konsensus politik di dalam negeri bahwa Indonesia tengah mengalami ancaman keamanan eksternal yang semakin serius, terutama mengingat tren militerisasi baik di Samudera Hindia dan Samudera Pasifik, perselisihan yang terjadi antara China dengan sejumlah negara Asia Tenggara di Laut China Selatan, dan kemungkinan klaim China terhadap perairan di sekitar kepulauan Natuna. ${ }^{17}$ Dalam konteks geopolitik, visi ini dapat dikatakan menegaskan kembali peta mental (mental map) yang melekat dalam bayangan parael elit politik di Indonesia mengenai eksistensi geografis Indonesia.

14 Ibid.

15 "BBC.Com.

2014 ,

http://Www.Bbc.Com/Indonesia/Berita

Indonesia/2014/06/140622_indonesia_

Debatcapres_dua) diakses pada hari Jumat tanggal 15 Maret 2019 Jam 14.10 WIB.

16 Laksmana. Evan A., Iis Gindarsah, and Andrew W. Mantong. Menerjemahkan Visi Poros Maritim Global ke Dalam kerangka Diplomasi Pertahanan Maritim Dalam Kebijakan Luar Negeri Indonesia di Era Jokowi 2018. Centre for Strategic and International Studies.Jakarta.(2014)

17 https://www.brookings.edu/articles/indonesia-as-amaritime-power-jokowis-vision-strategiesandobstacles-ahead/.) Shekar. Vibhanshu dan Joseph Chinyong Liow 2014, "Indonesia as a Maritime Power: Jokowi's Vision, Strategies, and Obstacles Ahead," Brookings, 7 November 2014. 
Pada umumnya, para pengambil kebijakan merasakan ketidakamanan dan ketakutan akan eksploitasi asing terhadap keberadaan sejumlah Alur Laut Kepulauan Indonesia beserta letak strategis Indonesia di antara dua benua dan dua samudera sehingga sering kali memunculkan urgensi untuk menerapkan kontrol dan patroli terhadap perarian Indonesia. ${ }^{18}$ Spesifik dalam konsepsi Poros Maritim Dunia adalah diakuinya kembali nilai strategis dari Samudera Hindia bersama-sama Samudera Pasifik sebagai samudera yang mengapit Indonesia. Dengan mencanangkan Poros Maritim Dunia, Presiden Joko Widodo dinilai bermaksud membawa kembali Samudera Hindia ke dalam "kanvas regional" seraya memproyeksikan kekuatan Indonesia. Dengan demikian, visi ini dapat dianggap sebagai upaya untuk menerjemahkan anggapan selama ini bahwa kebijakan luar negeri yang bertumpu semata-mata kepada ASEAN ${ }^{19}$ tidak lagi harus terus menjadi pijakan kebijakan luar negeri yang paling utama. Sehingga pengertian poros maritim dunia ini dituangkan dalam Peraturan Presiden Nomor 16 tahun 2017 yang berbunyi bahwa Poros Maritim Dunia adalah suatu visi Indonesia untuk menjadi sebuah negara maritim yang berdaulat, maju, mandiri, kuat, serta mampu memberikan kontribusi positif bagi keamanan dan perdamaian kawasan dan dunia sesuai dengan kepentingan nasional. ${ }^{20}$

\section{Berbagai Poros Maritim Dunia \\ a. Kemunculan Poros Maritim}

Tinjauan di atas menunjukkan ada dua jenis poros maritim yaitu poros maritim perantara dan poros maritim pusat. Poros maritim Mediterania Timur dan Barat, serta Nusantara adalah tipe poros maritim perantara karena perannya hanya sebagai jembatan bagi jalur perdagangan antar negara. Karakteristik dari poros maritim ini adalah berada pada dua atau tiga kawasan eksotis yang

18 Laksmana. Evan A., Iis Gindarsah, and Andrew W. Mantong. Menerjemahkan Visi Poros Maritim Global ke Dalam kerangka Diplomasi Pertahanan Maritim Dalam Kebijakan Luar Negeri Indonesia di Era Jokowi 2018. Centre for Strategic and International Studies, 2014. hlm. 97.

19 http://www.the Jakartapost.com/ news/ 2009/06/30/indonesia-needs-a-postasean-foreignpolicy.html) Sukma. Rizal. 2009, "Indonesia Needs a Post-ASEAN Foreign Policy," The Jakarta Post, 30 Juni 2009.

20 Peraturan Presiden Republik Indonesia Nomor 16 Tahun 2017 Tentang Kebijakan Kelautan Indonesia Pasal 1 Angka 1. berdekatan. Eksotis disini bermakna bahwa kawasan tersebut memiliki sumberdaya yang tidak ditemukan di kawasan lain. Yunani terletak antara Asia, Eropa, dan Afrika; Mediterania terletak antara Eropa dan Afrika; dan Nusantara terletak antara India dan Tiongkok. Poros jenis kedua adalah poros pusat. Karakteristik poros pusat adalah adanya pusat utama eksotis yang besar. Termasuk dalam poros ini adalah poros Persia, New England, dan Asia Timur. Masing-masing mewakili sumber eksotis Mesopotamia, Amerika Utara, dan Timur Jauh. ${ }^{21}$

NKRI (Negara Kesatuan Republik Indonesia) berdasarkan lokasinya merupakan bagian dari poros perantara. Walau begitu, situasi ini sebenarnya situasi yang baru. Di masa lalu, NKRI adalah sebuah poros ganda: perantara sekaligus pusat. Poros perantara ada di Malaka sementara poros pusat ada di Maluku, hal ini berkenaan dengan adanya kendali kerajaan yang terdapat di sana yang menguasai rempah-rempah dan memainkan peran sebagai aktor pada poros maritim pada saat itu. Dalam situasi modern, NKRI lebih ada pada poros perantara karena meredupnya kemampuan perdagangan Indonesia Timur akibat penjajahan dan orientasi darat serta menguatnya berbagai pesaing, termasuklah Singapura. Berpijak pada fakta tersebut, maka dapat dideskripsikan bahwa peran perdagangan memiliki andil yang sangat besar di dalam mempengaruhi suatu wilayah, daerah atau negara dalam perannya sebagai poros maritim, yaitu yang memegang kontrol atau kendali dalam memanfaatkan wilayah atau kawasan maritim dalam konteks poros maritim. Jadi dapat disimpulkan secara obyektif bahwa faktor ekonomi merupakan faktor terpenting untuk menggiring sebuah bangsa dan negara menjadi aktor utama dalam poros maritim. ${ }^{22}$

\section{b. Poros Maritim Klasik}

Terdapat beberapa poros maritim klasik yang sempat mendominasi kegiatan maritim dunia sepanjang sejarah. Poros-poros ini tersebar diberbagai kawasan yang beriringan dengan keberadaan kekuatan militer besar di kawasan tersebut. Pertama, poros maritim kepulauan

\footnotetext{
21 Ade Prasetia, "Menuju Indonesia Sebagai Poros Maritim Dunia" Kajian Strategis Perulangan Kebesaran Bangsa Melalui Optimalitas Geostrategis Nusantara. Jurnal Maritim Indonesia Juni 2015 Edisi-3. Diakses Melalui 22 Ibid.
} 
Yunani yang terletak di kawasan Mediterania Timur, melingkupi kawasan Laut Adriatik danAfrika ${ }^{23}$ Poros ini berkembang pada masa Yunani Kuno semenjak masa pra-Sokratik hingga masa modern. Kedua, poros maritim Mediterania Barat yang mengapit benua Eropa dan Afrika. Kawasan ini berkembang pada era Romawi dan terus berkembang hingga era Penjelajahan Samudera ${ }^{24}$ Poros ini telah berkembang sejak masa Mesopotamia dan terus berkembang di masa kini berkat penemuan minyak di kawasan Timur Tengah. Keempat, poros maritim New England yang menghubungkan Amerika Utara dan Eropa. ${ }^{25}$ Poros ini muncul pertama kali ketika bangsa Eropa menemukan benua Amerika dan berperan penting dalam pembentukan Amerika Serikat dan Kanada. Kelima, poros maritim Nusantara. Poros ini menghubungkan India dan Tiongkok, dua peradaban besar yang telah hadir sebelum masa sejarah di Nusantara sendiri. Ia merupakan bagian dari sistem yang lebih luas yang disebut sistem maritim Samudera Hindia yang merentang dari Afrika hingga Asia Tenggara, menyatukan poros maritim Persia dan Nusantara. ${ }^{26}$ Karenanya, poros ini telah sangat tua dan berperan besar dalam membentuk kebudayaan di Nusantara yang terpengaruh oleh kebudayaan India, Timur Tengah, dan Tiongkok.

\section{c. Poros Maritim Modern}

Peta maritim dunia telah berubah di masa modern ini akibat kebangkitan Tiongkok yang memiliki surplus sumber daya manusia yang besar. Pada dasarnya hanya tersisa dua poros maritim dunia diera modern ini, yaitu poros maritim Nusantara dan poros maritim Asia Timur. ${ }^{27}$ Poros maritim Asia Timur adalah poros maritim baru yang dikuasai oleh Korea Selatan dan Tiongkok. Poros maritim Nusantara tetap berada ditangan

23 Cocker, Blackmask. B.F. Christianity and Greek Philosophy, 2017 hlm. 17.

24 Lopez, E., Piquero, S. Was the Little Divergence so Big? Spanish Real Wages in the North Western European Mirror, 1500-1800. Pamplona-Iruna, 3(4), 2013, 1-30, hal. 11. Ketiga, Poros maritim Persia yang menghubungkan Timur Tengah, Afrika, dan India (Wills) hlm. 93.

25 G.M Roos, "2008, Hlm. 34.

26 Bulliet, "R.W., Crossley, P.K., Headrick, D.R., Hirsch, S.W., Johnson, L.L., Northrup, D. The Earth and Its People, 4th Edition, Boston:Cengange Learning, Hlm. G-8.

27 J-P Rodrigue, "Ports and Maritime Trade. Dalam The Encyclopedia of Geography, Warf, B (Ed), London: Sage, Hal. 4.
Singapura. Poros lainnya seperti Yunani, Mediterionia, New England, dan Persia, telah kalah bersaing. Walau begitu, Yunani tetap mampu memperoleh banyak manfaat dari sejarah kelautan yang panjang lewat armada lintas samudera yang telah dibangunnya. Yunani saat ini merupakan negara terbesar dalam kelautan dengan mengendalikan $16 \%$ armada kapal dunia dalam hal tonase. ${ }^{28}$ Jepang walaupun kalah dalam persaingan di poros Asia Timur tetap mampu mendapat banyak manfaat lewat armada penangkapan ikan yang memanfaatkan keterbukaan geografisnya dengan Samudera Pasifik.

Keberlangsungan poros maritim Nusantara hingga masa modern dibandingkan poros maritim lain di dunia menunjukkan bahwa kawasan Asia Tenggara merupakan kawasan yang sangat strategis dan berperan dalam menentukan kegiatan pelayaran dan perdagangan dunia. Walau begitu, pemain utama di poros maritim Nusantara bukanlah Indonesia. Ukuran lautan yang besar tampaknya justru menjadi kendala dibandingkan pemain utamanya, Singapura yang merupakan negara kecil di poros ini. Meskipun sebagai negara yang luas wilayahnya tidak seberapa, terlebih dibandingkan dengan negara tetangganya Malaysia dan Indonesia, akan tetapi Singapura telah memiliki perhatian yang begitu besar terhadap peran kemaritiman di dalam mendukung optimalitas perekonomian negaranya. Sehingga negara yang sangat minim dengan kandungan sumberdaya alam ini telah menjadi raksasa ekonomi dengan hanya memanfaatkan sektor kelautan dan kemaritiman. Hal ini sangat bertolak belakang dengan kondisi yang ada di Indonesia. Sebagai sebuah negara yang luas perairannya lebih dominan dari luas daratan, tenyata Indonesia sejauh ini belum memberikan perhatian serius dalam memanfaatkan geostrategis negara yang merupakan potensi yang sangat eksotik. Padahal ketika kembali berpijak dengan obyektifitas sejarah Nusantara, maka dua kerajaan besar di wilayah negara ini telah sangat optimal memanfaatkan wilayah Nusantara untuk mencapai predikat gemilang menuju kemegahan sebuah peradaban.

\section{d. Konsep Poros Maritim di Indonesia}

28 Nikolaou, J. Op-Ed: Greece Remains at Top of Shipping Economy. Maritime Executive, 19 Februari 2019. http://www.maritimeexecutive. com/article/OpEd-Greece-Remains-at-Top-ofShipping-Economy-2019-02-19. Diakses pada tanggal 11 Maret 2019 pukul 14.01 W IB. 
Berkaca dari masa lalu, melihat bagaimana kejayaan masa lampau diperoleh karena mengoptimalkan potensi laut sebagai sarana dalam suksesnya perekonomian dan ketahanan suatu negara, maka menjadi suatu hal yang wajar bila sekarang ini Indonesia harus lebih mengembangkan laut demi tercapianya tujuan nasional. Indonesia menyandang predikat "Negara Maritim" atau negara kepulauan, predikat ini mustahil ditinggalkan, lain halnya dengan predikat "Negara Agraris" yang suatu saat bisa berganti dengan industri. Konsekuensi sifat maritim itu sendiri lebih mengarah pada terwujudnya aktifitas pelayaran di wilayah Indonesia. Dalam kalimat ini bahwa Indonesia sebagai negara kepulauan dalam membangun perekonomian akan senantiasa dilandasi oleh aktivitas pelayaran. ${ }^{29}$

Kilasan sejarah itu tentunya memberi gambaran, betapa kerajaan-kerajaan di Nusantara dulu mampu menyatukan wilayah nusantara dan disegani bangsa lain karena, paradigma masyarakatnya yang mampu menciptakan konsep poros maritim sebagai bagian utama dari kemajuan budaya, ekonomi, politik dan sosial. Laut Indonesia merupakan urat nadi perekonomian nasioal dan penggerak lalu lintas ekonomi dunia. Indonesia secara natural lahir dan tumbuh sebagai Negara dan bangsa maritim, luar dan dalam. Hanya faktanya, Indonesia saat ini masih belum menjadi Negara maritim dalam pengertian yang sesungguhnya. Sebab, hingga sekarang Indonesia belum menjadi aktor atau pelaku kelautan yang cukup mempuni, baik ditingkat domestik maupun global. Padahal laut Indonesia merupakan urat nadi perekonomian nasional dan penggerak lalu lintas ekonomi dunia. Dunia maritim Indonesia telah mengalami kemunduran yang cukup signifikan, kalau pada zaman dahulu mencapai kejayan baik dalam bidang politik maupun ekonomi, sekarang ini tidak tampak sedikitpun kemajuan yang dapat dilihat. Berdasarkan tinjauan sejarah dari berbagai kerajaan di Nusantara pada masa lalu, Indonesia sebenarnya adalah negara yang berwatak maritim sehingga menjadi bangsa yang kuat dan disegani dimata internasional. ${ }^{30}$

Presiden menjelaskan pada agenda pembangunan agar dapat mewujudkan Poros Maritim Dunia tersebut. Pertama adalah dengan membangun kembali budaya maritim Indonesia.

\footnotetext{
29 http://Blogspot.Com/2017/02/Penyebab-KenapaIndonesia-Disebut.Html Diakses Pada Hari Senin 11 Maret 2019).” Jam 10.08 WIB.

30 Ibid.
}

Sebagai negara yang terdiri dari jumlah pulaunya lebih dari 13.500 buah dan mencakup wilayah sepanjang 3.000 mil laut, bangsa Indonesia harus menyadari dan melihat dirinya sebagai bangsa yang identitasnya, kemakmurannya, dan masa depannya, sangat ditentukan oleh bagaimana kita mengelola samudera. Indonesia merupakan Negara Kelautan terbesar di dunia yang memiliki bentang laut luas dengan ribuan pulau besar dan kecil. Indonesia merupakan negara dengan pantai terpanjang kedua di dunia setelah Kanada. Indonesia terletak pada posisi geografis sangat strategis, terletak di antara persilangan dua benua dan dua samudera, serta memiliki wilayah laut yang menjadi urat nadi perdagangan dunia. Luas wilayah laut Indonesia mencapai $3 / 4$ dari seluruh wilayah Indonesia. Selat Malaka dan jalur Alur Laut Kepulauan Indonesia (ALKI) secara umum merupakan jalur perdagangan strategis yang dilalui kapal-kapal perdagangan dunia dengan volume perdagangan mencapai 45 persen dari total nilai perdagangan seluruh dunia. Sampai saat ini, laut Indonesia berpotensi meningkat di masa-masa datang, mengingat prospek perkembangan perekonomian di wilayah Asia masih menjanjikan 31. Kedua adalah dengan menjaga dan mengelola sumber daya laut, berfokus pada kedaulatan pangan laut, melalui pengembangan industri perikanan, dengan menempatkan nelayan sebagai pilar utama. Kekayaan maritim akan digunakan sebesar-sebesarnya untuk kepentingan rakyat. Potensi Laut Indonesia memberikan peluang kesejahteraan dan kemakmuran karena Indonesia memiliki Zona Ekonomi Eksklusif (ZEE) yang terbentang seluas 2,4 juta kilometer persegi dengan berbagai potensi kekayaan alam yang siap dieksploitasi di dalamnya. Potensi ekonomi tersebut menjanjikan bagi prospek pencapaian kinerja perekonomian yang mampu menyejahterakan rakyat. Potensi perekonomian kelautan dapat dikembangkan dari berbagai sektor, terutama sektor perikanan tangkap, sektor perikanan budidaya, sektor pengolahan perikanan, sektor jasa pelabuhan, eksplorasi dan eksploitasi sumberdaya energi lepas laut, terutama pada kawasan ZEE, kehutanan, pesisir, perdagangan, pelayaran dan pariwisata. ${ }^{32}$ Ketiga adalah dengan

31 http://Jurnalmaritim.Com/2014/08/Indonesia-PorosMaritim-Dunia-Menuju-Ekonomi-Berbasis-

Kelautan/." Diakses pada hari selasa Jam 10.09 WIB.

32 http://Bisniskeuangan.Kompas.Com/Read/ 2014/ 10/21/203422926/Visi.Maritim.Jokowi. Tantangan. 
memprioritaskan pengembangan infrastruktur dan konektivitas maritim, melalui pembangunan tol laut, deep seaport, logistik, dan industri perkapalan, dan pariwisata maritim. Paradigma pembangunan pun harus digeser menjadi berorientasi pada wilayah maritim yang terintegrasi dengan pembangunan wilayah darat. Paradigma ini menegaskan jaminan bahwa pembangunan maritim pada akhirnya akan membantu peningkatan efisiensi dan efektivitas pada aktivitas perekonomian yang berkembang di wilayah darat. Pemerintah melalui Kementerian Perencanaan Pembangunan Nasional $(\mathrm{PPN}) /$ Bappenas merinci secara detail pembangunan tol laut selama lima tahun ke depan dalam mendukung poros maritim dunia. Adapun 24 pelabuhan itu, yakni Pelabuhan Banda Aceh, Belawan, Kuala Tanjung, Dumai, Batam, Padang, Pangkal Pinang, Pelabuhan Panjang, Pelabuhan Tanjung Priok, Cilacap, Tanjung Perak, Lombok, Kupang, Pontianak, Palangkaraya, Banjarmasin, Maloy, Makassar. ${ }^{33}$ Keempat dari strategi Poros Maritim adalah melalui diplomasi maritim. Pemerintah mengajak semua mitra-mitra Indonesia untuk bekerjasama dibidang kelautan ini baik dalam maupun luar negeri. Bekerja sama untuk menghilangkan sumber konflik di laut, seperti pencurian ikan, pelanggaran kedaulatan, sengketa wilayah, perompakan, dan pencemaran laut. Sebagai negara berkembang yang masih kekurangan kemampuan teknologi untuk mengeksplorasi dan mengeksploitasi kekayaan bawah laut, Indonesia harus membangun kerja sama lebih erat dengan negara-negara berteknologi maju untuk mengeksplorasi, mengeksploitasi sekaligus mengkonservasi dan menjaga sumbersumber laut. Kelima, Indonesia memiliki kewajiban untuk membangun kekuatan pertahanan maritim. Hal tersebut diperlukan bukan saja untuk menjaga kedaulatan dan kekayaan maritim indonesia, tetapi juga sebagai bentuk tanggungjawab dalam menjaga keselamatan pelayaran dan keamanan maritim sehingga posisi sebagai poros maritim dunia membuka peluang bagi Indonesia untuk membangun kerjasama regional dan internasional bagi kemakmuran rakyat.

Bernilai.Ribuan. Triliun.Rupiah.)."diakses pada hari selasa tanggal 14 Mei 2019 jam 10.37 WIB.

33 http://M.Liputan6.Com/Bisnis/Read/2138321/

Melongok-Tol-Laut-Jokowi-Modal-Ri-Jadi-Poros-

Maritim-Dunia), Diakses Pada Hari Selasa Tanggal 14 Mei 2019 Jam 13.12 WIB.

\section{B. Implementasi Poros Maritim Indonesia dari Prespektif Kebijakan}

Orientasi pembangunan Indonesia selama ini terfokus pada pembangunan berbasis daratan. Selain payung hukum yang belum memadai, hal ini tergambar dari aspek kelembagaan dan politik anggaran yang mengabaikan pembangunan sektor kelautan dan perikanan. Kelembagaan yang lemah dan politik anggaran yang tidak memadai menyebabkan pembangunan sektor maritim terbengkalai. ${ }^{34}$

\section{a. NKRI sebagai Poros Maritim Dunia}

Untuk dapat membangkitkan Indonesia sebagai sebuah poros maritim dunia, ada dua jalan untuk mengalahkan Singapura atau menjadi sebuah poros pusat. Opsi pertama akan sangat sulit karena Singapura telah jauh meninggal Indonesia dan memiliki kampanye negatif yang efektif dalam menjauhkan kapal-kapal dari kawasan laut dalam Indonesia. Selain itu, budaya konsumtif dan orientasi darat yang telah sangat lama terjadi di Indonesia harus terlebih dahulu dihilangkan sebelum berupaya mengalahkan Singapura.

Opsi yang lebih mungkin adalah menjadikan kembali Indonesia sebagai poros sentral. Hal ini dilakukan dengan menggiatkan kembali perdagangan laut dalam Indonesia, menjamin keamanan pelayaran di laut dalam, dan upaya promosi gencar produk-produk khas Indonesia ke pasaran mancanegara. Upaya ini dilakukan secara merata agar seluruh kawasan Indonesia dapat memperoleh aliran pelayaran yang seimbang. Potensi-potensi sebenarnya ada dan tinggal dibawa ke permukaan lewat upaya pemasaran yang agresif. Menurut kompas.com pada 21 Oktober 2014 lalu, Indonesia memiliki tiga alur laut kepulauan Indonesia (ALKI) dengan potensi nilai perdagangan 1,5 juta dollar AS per hari, setara dengan sekitar Rp 18 miliar perhari. Berdasarkan data Badan Pangan Dunia (FAO), nilai perekonomian dari laut Indonesia diperkirakan mencapai 3 triliun dollar AS sampai 5 triliun dollar AS, setara Rp 36.000 triliun sampai Rp 60.000 triliun pertahun. ${ }^{35}$ Kekayaan sumber daya alam yang besar itu banyak yang dijarah asing, sehingga

34 Limbong. Bernhard. Poros Maritim. Pustaka Margareta. Jakarta. (2015)

35 http://Bisniskeuangan.Kompas.Com/Read/2014/ 10/21/203422926/ Visi. Maritim. Jokowi. Tantangan. Bernilai. Ribuan. Triliun. Rupiah.)." diakses pada hari Selasa tanggal 14 Mei 2019 Jam 10.41 WIB. 


\section{De Jure}

nilai ikan yang dicuri oleh nelayan asing dari wilayah laut di Indonesia tak kurang dari 23 miliar dollar AS atau sekitar Rp 276 triliun per tahun. Karenanya, pemerintah diharapkan benar-benar berkomitmen mengembalikan kekayaan maritim Indonesia. ${ }^{36}$

Berpijak pada potensi alami yang dimiliki oleh Indonesia, maka geostrategis NKRI merupakan suatu alasan krusial yang tidak dapat dibantahkan lagi; menjadi suatu variabel utama dalam peran Indonesia sebagai Poros Maritim Dunia. Luas wilayah (Dua pertiga kawasan Asia Tenggara adalah wilayah kedaulatan Indonesia. Selain itu, dua pertiga perairan Asia Tenggara merupakan perairan yurisdiksi Indonesia, ${ }^{37}$ dan bentuk negara yang merupakan negara kepulauan serta kestrategisan letak negara (Indonesia terletak pada posisi silang, yakni di antara dua benua, yaitu Benua Asia dan Australia; serta di antara dua samudera, Samudera Hindia dan Samudera Pasifik, Indonesia memiliki perairan yang menjadi salah satu urat nadi perdagangan internasional. Hal ini telah berlangsung sejak lama dan karena alasan kestrategisan inilah ketika Indonesia dahulu masih bernama Nusantara menjadi perebutan banyak pihak asing untuk menanamkan pengaruh, ekspansi ekonomi bahkan berkeinginan untuk menjajah. Hal ini menjadi faktor pendorong utama dalam mengukur kemampuan Indonesia dalam menyandang predikat tersebut. Sebagai salah satu negara terbanyak penduduknya di dunia, pemerintah tinggal mengarahkan masyarakat agar tertarik pada mata pencarian di bidang kelautan. Penganggaran yang lebih baik dapat dilakukan untuk mendorong pembangunan infrastruktur yang membantu penyaluran hasil kreatifitas maupun sumberdaya alam negara lewat laut. Begitu pula, posisi Indonesia yang berbatasan dengan dua samudera sekaligus memungkinkan negara ini untuk mengembangkan armada samudera untuk kawasan barat (Sumatera-Jawa) maupun timur Maluku-Papua) yang menjelajah Samudera Hindia dan Pasifik.

36 "Indonesia Sebagai Poros Maritim Dikases Melalui : http://Www.Bppk.Kemenkeu.Go.Id/ Id/ Publikasi/Artikel/150-Artikel-Keuangan-Umum/ 20555-Poros-Maritim-Dan-Perkembangan-Pereko nomian-Indonesia.)" .diakses pada hari Selasa tanggal 14 Mei 2019 jam 10. 45 WIB.

37 Susilo Bambang Yudhoyono, "Geopolitik Kawasan Asia Tenggara: Perspektif Maritim. Http://Jakartagreater.Com/ Geopolitik-KawasanAsiatenggara/. Diakses Pada Tanggal 12 Maret 2019 Pukul 10.10 WIB).

\section{b. Cita-Cita Indonesia Menjadi Poros Maritim Dunia}

Di berbagai kesempatan, baik di dalam maupun luar negeri, Presiden RI Joko Widodo memaparkan cita-cita Indonesia menjadi Poros Maritim Dunia. Pada acara Konferensi Tingkat Tinggi (KTT) Asia Timur di Nay Pyi Taw, Myanmar, Kamis 13 November 2014 Presiden Joko Widodo memaparkan visi Indonesia untuk menjadi negara poros maritim dunia. Menurutnya, sebuah transformasi besar sedang terjadi pada abad ke-21 ini. Pusat gravitasi, geoekonomi, dan geopolitik dunia sedang bergeser dari Barat ke Asia Timur. Negara-negara Asia sedang bangkit. Dengan pertumbuhan ekonomi rata-rata $7 \%$ per tahun dan total GDP sekitar US\$ 40 triliun, Asia Timur merupakan kawasan paling dinamis secara ekonomi. Sekitar $40 \%$ perdagangan dunia ada di kawasan ini. ${ }^{38}$

Dalam dinamika itu, laut akan semakin penting artinya bagi masa depan kita. Jalur laut yang menghubungkan dua samudra strategis (Hindia dan Pasifik) merupakan jalur penting bagi lalu lintas perdagangan dunia. Tiga Alur Laut Kepulauan Indonesia (ALKI) merupakan "lorong" lalu lintas maritim dunia. Dua samudra strategis itu juga menyimpan kekayaan besar (energi dan sumber daya laut lainnya) yang akan menentukan masa depan kemakmuran di kawasan. Oleh karena itu, sebagai negara maritim, Indonesia harus menegaskan dirinya sebagai Poros Maritim Dunia, sebagai kekuatan yang berada di antara dua samudra. Secara geografis, Indonesia berada di antara dua samudra (Pasifik dan Hindia). Negara kepulauan ini juga terletak di antara dua benua (Asia dan Australia). Posisi silang ini sangat strategis, baik dilihat dari politik dan ekonomi. Inilah mengapa Indonesia layak mengukuhkan sebagai Poros Maritim Dunia. ${ }^{39}$

Ketua DPR RI Bambang Soesatyo dalam Seminar 'Konsepsi Strategis Pengembangan Potensi Maritim Nasional dalam Mewujudkan Cita-cita Poros Maritim Dunia Menuju 100 Tahun Kemerdekaan Republik Indonesia' di kompleks parlemen, Senayan Jakarta, 12 April 2018, mengatakan bahwa sudah saatnya pemerintah membangun pusat-pusat unggulan kelautan di seluruh pelosok tanah air. Hal tersebut harus

38 Subandono Diposaptono, "Membangun Poros Maritim Dunia Dalam Perspektif Tata Ruang Laut. Cetakan Ke 3 Kementerian Kelautan Dan Perikanan.(2017): 41.

39 Ibid.hal. 42. 
dilakukan agar cita-cita mewujudkan Indonesia sebagai negara poros maritim dunia bisa segera terwujud. Indonesia ditakdirkan sebagai bangsa kepulauan atau bangsa maritim. Sebab, lebih dari dua pertiga wilayah negara Indonesia terdiri dari laut. Potensi sumber daya laut Indonesia juga sangat besar, yakni mencapai Rp 17 ribu triliun per tahun. Maka diperlukan terobosan untuk mempercepat pembangunan infrastruktur, pengembangan sumber daya manusia, serta teknologi di bidang kelautan. Teknologi kemaritiman harus diperkuat. Riset pendidikan dan pengembangan di bidang kelautan harus dikembangkan. Demikian juga dengan industri di bidang kemaritiman, perkapalan dan pelayaran harus pula dikembangkan secara maksimal. Disamping itu di laut ada cadangan minyak dan gas yang besar, potensi kekayaan ikan yang luar biasa, pariwisata laut yang mempesona, bahkan ombak dan gelombang dapat dijadikan sumber energi listrik yang sangat potensial. Kekayaan sumber daya laut yang besar itu harus digunakan untuk kesejahteraan dan kemakmuran seluruh rakyat Indonesia. ${ }^{40}$

Cita-cita dan agenda di atas akan menjadi fokus Indonesia di abad ke-21. Indonesia akan menjadi Poros Maritim Dunia, kekuatan yang mengarungi dua samudra, sebagai bangsa bahari yang sejahtera dan berwibawa. Demikina juga dengan tata ruang laut dapat membantu menegakkan lima pilar poros maritim dunia. Pertama, tata ruang laut mengalokasikan ruang laut yang strategis untuk kepentingan sosial, ekonomi, budaya, pertahanan, dan keamanan. Kedua, tata ruang laut dapat mensinergikan antara pemanfaatan ekonomi dan perlindungan/konservasi sumber daya laut. Ketiga, tata ruang laut menggerakkan investasi ekonomi dan menyambungkan potensi antarwilayah dalam konektivitas ekonomi dan sumber daya beserta infrastrukturnya. Keempat, tata ruang laut di wilayah perbatasan memberikan kekuatan diplomasi Negara untuk memperjuangkan kepentingan nasional. Lainnya, tata ruang laut juga melindungi adat, budaya, serta kearifan lokal di laut.

\footnotetext{
40 https://www.Gatra.Com/Rubrik/Info-DPR/ 316965 Indonesia-Sebagai-Poros-Kemaritiman-Dunia Diakses Pada Hari Kamis, Tanggal 16 Mei 2019, Jam 10. 44 WIB.
}

\section{c. Kebijakan pada Poros Maritim Indonesia}

Kebijakan poros maritim yang menjadi bagian dari poros maritim dunia menunjukkan adanya pilihan antara kebijakan domestik dengan kebijakan internasional. Pilihan internasional dan domestik dalam kebijakan tersebut menunjukkan adanya intermestik ${ }^{41}$ Kebijakan poros maritim pada visi dan misi Presiden menunjukkan orientasi kebijakan luar negeri Jokowi pada geopolitik maritim. Konsep geopolitik maritim mengadopsi teori geopolitik Alfred Thayer Mahan sebagai pelopor orientasi maritim yang membuktikan bahwa kekuatan laut merupakan instrumen negara untuk menguasai dunia. ${ }^{42}$ Pandangan Mahan ini merupakan gambaran dari pengelolaan laut yang baik oleh Amerika Serikat sebagai orientasi kekuatan sumber ekonomi dan pertahanan negara dimasa itu.

Hasjim Djalal mengemukakan bahwa negara maritim tidak sama dengan negara kepulauan ${ }^{43}$. Negara maritim adalah negara yang mampu memanfaatkan laut, walaupun negara tersebut mungkin tidak memiliki banyak laut, tetapi mempunyai kemampuan teknologi, ilmu pengetahuan, peralatan, dan lain-lain untuk mengelola dan memanfaatkan laut tersebut, baik ruangnya maupun kekayaan alamnya dan letaknya yang strategis. Oleh karena itu, banyak negara kepulauan atau negara pulau yang belum menjadi negara maritim karena belum mampu memanfaatkan laut yang sudah berada didalam kekuasaannya ${ }^{44}$ Dengan demikian dapat dikatakan bahwa Indonesia tergolong negara kepulauan dan belum sebagai negara maritim karena dalam kebijakan kelautan atas sektor maritim masih terjadi tumpang tindih, misalnya urusan

41 Kawilarang. Renne R.A, "Warisan Besar Menlu Hassan Wirajuda," dalam http://www.viva.co.id/ berita/dunia/98969-warisan-besar-menlu-hassanwirajuda 2009. diakses pada tanggal 12 Maret 2019 Jam. 10.15 WIB.

42 Allan Westcoot, (Ed). Mahan on Naval Warfare, Selections from the Writing of Rear Admiral Alfred T. Mahan, (Mineola, New York: Dover Publications, 1985).

43 Hasjim Djalal, "Singapura Sudah Menjadi Negara Maritim, Indonesia Belum. Diakses Melalui Http://Lan.Go.Id/Id/Berita-Lan/Hasjim-Djalal-

Singapura-Sudah-Menjadi-Negara-MaritimIndonesia-Belum Pada Hari Selasa Tanggal $14 \mathrm{Mei}$ 2019 Jam 10.05 WIB)

44 Safril Hidayat dan Ridwan, "Kebijakan Poros Maritim Dan Keamanan Nasional Indonesia: Tantangan Dan Harapan.” 
kemaritiman dicampur adukan dengan urusan kelautan, hal ini menjadi penghambat utama penjabaran kebijakan poros maritim dunia yang dicanangkan Pemerintah Indonesia. Tanpa kebijakan yang jelas, Indonesia tidak mampu memanfaatkan posisi strategis dalam kemaritiman dunia hingga saat ini. ${ }^{45}$. Dasar kebijakan kemaritim Indonesia seharusnya Undang-Undang Nomor 17 Tahun 2008 tentang Pelayaran. Yang menjadi sektor maritim justru diatur dengan kebijakan kelautan, ini dua hal yang berbeda. Kemudian soal keselamatan pelayaran yang wajib dipenuhi pemerintah dengan menyediakan navigasi laut dan penjaga pantai.

\section{d. Penegakan Hukum pada Poros Maritim di Indonesia}

Berbicara hukum tidak lepas dengan penegakan hukum pada poros maritim di Indonesia. Secara teroritis, aktor utama yang memiliki kewenangan dalam poros maritim untuk melakukan kontrol atas arus lintas laut adalah Polisi Perairan (Polair), Petugas Imigrasi, dan Petugas Bea Cukai. ${ }^{46}$ Polair, tugas utamanya adalah pencegahan dan penindakan terhadap aktifitas arus lintas barang dan orang yang bersifat illegal, pendeteksian ancaman keamanan, serta pengontrolan terhadap orang dan barang di titik awal hingga tujuan, penyelidikan dan penyidikan tindak kejahatan atau pun peristiwa kecelakaan/insiden. Petugas Imigrasi bertanggung jawab untuk melakukan kontrol persyaratan dan pelarangan masuk barang dan orang, menjamin legalitas dari dokumen perjalanan, mengidentifikasi dan menginvestigasi tindak kejahatan, dan membantu orang-orang yang membutuhkan pertolongan. Petugas bea cukai pada dasarnya bertugas untuk mengatur arus barang dan jasa. Fungsinya adalah memfasilitasi perdagangan sesuai persyaratan yang ditentukan tentang keluar masuk barang, memastikan pelaksanaan bea dan pajak masuk, serta melindungi kesehatan arus lintas manusia, hewan dan binatang. Namun, pada kenyataannya di Indonesia terdapat 12 (dua belas) instansi yang melakukan penegakan hukum dan peraturan tentang laut secara bersama-sama. Lembaga-lembaga tersebut mempunyai landasan

45 Kompas, Rabu 9 November 2017 (4). Masih Terjadi Tumpang Tindih Kebijakan.

46 Kadar. A,"Pengelolaan Kemaritiman Menuju Indonesia sebagai Poros Maritim Dunia." Peneliti di Lembaga Concern (Consultancy and Research). Jurnal Keamanan Nasional Vol. I.Nomor 3. 2015. hukum masing-masing yang isinya hampir bersinggungan. Meski bersinggungan, dalam menjalankan fungsinya sebagai penegak hukum di wilayah laut Indonesia, sehingga pengamanan dan penegakan hukum belum berjalan maksimal. Masing-masing instansi/kementerian terkait mempunyai kebijakan, sarana dan prasarana, serta sumber daya manusia yang berbeda-beda, berdasarkan tugas pokok dan fungsinya yang telah ditentukan.

Dalam pemerintahan Presiden Joko Widodo, mencoba merubah sistem kelembagaan multi agent menjadi single agent untuk penegakan hukum di laut Indonesia. Bakorkamla yang awalnya hanya sebagai koordinator direvitalisasi pada tanggal 8 Desember 2014 menjadi Badan Keamanan Laut Indonesia (Bakamla) dengan wewenang yang lebih luas sampai dengan kewenangan untuk menindak segala bentuk kejahatan di laut. Hal ini menimbulkan pro dan kontra, karena persoalan utama yang terjadi adalah kurangnya koordinasi antar lembaga, bukan membuat lembaga baru. Lembaga yang sudah ada memang dijalankan sesuai tupoksi masing-masing dan ini mengindikasikan peran spesifik dari masingmasing lembaga (spesialisasi). Peran spesialiasi inilah yang harus diperkuat melalui fungsi koordinasi. Misalnya Kementerian Perhubungan, khususnya Ditjen Perhubungan Laut (dulunya Jawatan Pelayaran). Tugasnya adalah memelihara keamanan, keselamatan navigasi dan menjaga marine pollution. Armada KPLP (Kesatuan Penjaga Laut dan Pantai) Direktorat Jenderal Perhubungan Laut bertugas sebagai penjaga pantai dan penegakan hukum di laut. Ada dasar hukumnya dan diakui oleh hukum internasional. Direktorat Jenderal Bea dan Cukai (P2) bertugas mengawasi lalu lintas barang masuk dan keluar NKRI umumnya, pelanggaran khususnya, lebih khusus lagi adalah tugas mendeteksi dan menangkap penyelundupan di wilayah perairan Indonesia. Kementerian Perhubungan dibantu Kementerian Kelautan dan Perikanan (KKP) bertugas meningkatkan efektivitas dan efisiensi perhubungan antar pulau, hubungan laut dan udara, terutama pengangkutan hasil laut ke pasar luar/antar pulau dengan landasan dan pesawat kecil. Kementerian bertugas membongkar berbagai hambatan "tol laut" dalam sebuah rangkaian dari pulau Sumatera sampai Papua. KKP bertugas mengamankan kekayaan laut dan perikanan melalui moratorium (larangan sementara, izin masuk zona tangkap bersyarat khusus) penangkapan ikan pada wilayah over fishing, 
seleksi ulang izin usaha, pengetatan persyaratan dan perizinan usaha penangkapan ikan, aturan bongkar muat di tengah laut, mengembangkan angkutan hasil laut lewat udara, sistem satelit penginderaan jauh VMS dan MCS, sosialisasi pertahanan sipil, pembinaan masyarakat nelayan, dan pemeriksaan kapal di pelabuhan sebelum dan setelah melaut. Kementerian ESDM bertugas mengawasi pekerjaan usaha pertambangan dan pengawasan hasil pertambahan di perairan Indonesia. Kementerian Kebudayaan dan Pariwisata bertugas mengawasi dan melindungi cagar budaya, keselamatan wisatawan, kelestarian kualitas lingkungan di perairan Indonesia. Kementerian Hukum dan Hak Asasi Manusia bertugas melakukan pengawasan, penyelenggaraan keimigrasian, dan penyidikan tindak pidana keimigrasian. Kementerian Pertanian bertugas melakukan karantina hewan, ikan dan tumbuhtumbuhan. Kementerian Kehutanan dan Lingkungan Hidup bertugas melakukan pengawasan terhadap ilegal logging, abrasi daratan akibat penggundulan hutan, serta di bidang lingkungan hidup pada wilayah perairan Indonesia umumnya, kualitas air, hutan bakau, dan taman karang khususnya. Kementerian Kesehatan bertugas melakukan pengawasan atau pemeriksaan kapal, awak kapal, penumpang, hewan, barang, dan jenis muatan kapal yang lain. Kementerian Dalam Negeri bertugas melaksanakan otonomi daerah bidang perairan tiap Pemda di Indonesia. Sedangkan Polair yang merupakan bagian dari Polri, jelas merupakan institusi berdasarkan undang-undang menjalankan fungsi penyelidikan dan penyidikan tindak pidana kejahatan dengan dukungan forensik, dan diakui oleh hukum internasional. Fungsi kontrol dalam poros maritim memang perlu dilaksanakan melalui pendekatan integratif antar aktor yang berwenang. Hal ini dengan mempertimbangkan bentang laut seharusnya terdapat mekanisme koordinatif pembagian kerja antara patroli laut, pengamanan keluar masuk arus manusia dan barang di sejumlah pelabuhan melalui kontrol dokumen perjalanan dan kebijakan bea serta dukungan sistem pengawasan (surveillance). Namun, sentimen sektoral dan minimnya dukungan anggaran seringkali menjadi hambatan untuk pengembangan fungsi koordinatif seperti sudah disebutkan di atas. Sehingga aktor yang seharusnya bertanggung jawab melakukan fungsi kontrol melalui kerja koordinatif, akhirnya berjalan sendiri-sendiri dengan semangat ego sektoral. Masing-masing lembaga memiliki spesialisasi tertentu dalam ranah tupoksinya.
Pembentukan Bakamla jelas menjadikan kerancuan dalam upaya mewujudkan penegakan hukum di laut. Karena akan terlalu banyak aturan dan perundangan yang harus diubah dan akan memakan waktu serta biaya yang tidak sedikit. Tidak semudah memindahkan sarana dan prasarana kerja dengan hanya surat pemberitahuan. Karena ranah kerja institusi/lembaga hukum tersebut terikat dalam kaidah hukum internasional yang berlaku.

Pergulatan Tentara Nasional Indonesia perlu memusatkan perhatian pada tugas pokoknya menjaga pertahanan nasional, sehingga sebagai implikasinya mesti melepaskan tanggung jawab di sektor keamanan dalam negeri. Reformasi TNI perlu diimplementasikan. Salah satu poin yang menjadi perhatiannya adalah penentuan batas antara urusan pertahanan dan keamanan. Masih ada salah pengertian bahwa keamanan laut dan keamanan maritim berada di tangan TNI Angkatan Laut. Perlu ditanamkan pengertian, fungsi keamanan maritim merupakan fungsi penegakan hukum di wilayah perairan nasional yang dilaksanakan oleh lembaga penegak hukum sipil.

Saat ini penegakan hukum dan keamanan di lautan Indonesia memang masih tumpang-tindih (overlapping). Hingga saat ini setidaknya ada 24 peraturan perundang-undangan yang memberikan kewenangan kepada berbagai instansi pemerintah untuk menegakkan hukum di laut. Beberapa contoh diantaranya, UU Nomor 11 tahun 1967 Tentang Ketentuan-Ketentuan Pokok Pertambangan memberikan kewenangan penegakan hukum di laut kepada Kementerian Energi dan Sumberdaya Mineral. Kewenangan penegakan hukum di laut diberikan lagi kepada lembaga ini oleh UU Nomor 22 tahun 2001 Tentang Minyak dan Gas Bumi sehingga kewenangannya menjadi cukup luas. Kemudian contoh lain, UU Nomor 9 tahun 1992 Tentang Keimigrasian memberikan kewenangan kepada Kementerian Hukum dan HAM (dalam hal ini Ditjen Imigrasi) untuk juga menegakkan hukum di laut. Ada juga UU Nomor 2 tahun 2002 Tentang Kepolisian Negara RI yang memberikan kewenangan kepada Polri untuk menegakkan hukum di laut. Dalam UU Nomor 34 Tahun 2004 tentang TNI, pasal 9 disebutkan Angkatan Laut bertugas: a. melaksanakan tugas TNI matra laut di bidang pertahanan; b. menegakkan hukum dan menjaga keamanan di wilayah laut yurisdiksi nasional sesuai dengan ketentuan hukum nasional dan hukum internasional yang telah diratifikasi; $c$. 
melaksanakan tugas diplomasi Angkatan Laut dalam rangka mendukung kebijakan politik luar negeri yang ditetapkan oleh pemerintah; $d$. melaksanakan tugas TNI dalam pembangunan dan pengembangan kekuatan matra laut; e. melaksanakan pemberdayaan wilayah pertahanan laut. Dalam penjelasan atas UU Nomor 34 tahun 2004 Tentang Tentara Nasional Indonesia, Pasal 9 huruf a cukup jelas. Huruf $b$, yang dimaksud dengan menegakkan hukum dan menjaga keamanan adalah segala bentuk kegiatan yang berhubungan dengan penegakan hukum di laut sesuai dengan kewenangan TNI AL (constabulary function) yang berlaku secara universal dan sesuai dengan ketentuan perundang-undangan yang berlaku untuk mengatasi ancaman tindakan kekerasan, ancaman navigasi, serta pelanggaran hukum di wilayah laut yurisdiksi nasional.

Penegakkan hukum yang dilaksanakan oleh TNI AL, terbatas dalam lingkup pengejaran, penangkapan, penyelidikan, dan penyidikan perkara yang selanjutnya diserahkan kepada Kejaksaan, karena TNI AL tidak menyelenggarakan pengadilan. Memang perlu ada kejelasan peraturan yang saling tumpang tindih, maklum banyak undang-undang disusun secara cepat. Tapi yang pasti akibatnya, TNI AL punya wewenang penegakan hukum (polisionil) disamping sebagai alat pertahanan. Situasi tersebut telah menimbulkan kebingungan bagi obyek penegakan hukum di laut seperti kapal niaga, kapal penangkap ikan, nelayan, pelaut dan mereka yang karena sifat pekerjaannya harus bersinggungan dengan laut. Mereka mengungkapkan, instansi tertentu sering memberhentikan dan naik ke kapal di tengah lautan untuk memeriksa berbagai persyaratan yang harus ada di atas kapal atau dokumen/surat yang harus dimiliki oleh ABK, bagi aparat penegak hukum, ini sah-sah saja. Di sisi lain, sesuai dengan Hukum Maritim Internasional yang sudah disepakati Indonesia sejak tahun 1974 (SOLAS 1974) yang tertuang dalam: a. Bab V Peraturan 15 Konvensi Internasional tentang Keselamatan Jiwa di Laut (SOLAS 1974) mengenai kewajiban negara penandatangan untuk membentuk organisasi Pengawal Pantai (Coast Guard) atau Pengawal Laut dan Pantai (Sea and Coast Guard). b. Ketentuan Internasional tentang Keamanan Kapal dan Fasilitas Pelabuhan Tahun 2002 atau International Ships and Port Facilities Security Code 2002 (ISPS Code 2002) mengenai kewajiban negara peserta untuk menetapkan otoritas nasional dan otoritas lokal yang bertanggungjawab atas keselamatan dan keamanan maritim. c. Pasal 217, pasal 218 dan pasal 220 Konvensi Perserikatan Bangsabangsa tentang Hukum Laut (UNCLOS III, 1982) mengenai penegakan hukum oleh Negara Bendera (Flag State), oleh Negara Pelabuhan (Port State), dan oleh Negara Pantai (Coastal State). Berdasarkan aturan ini, organisasi militer dilarang untuk menegakan hukum maritim internasional di kapalkapal berbendera asing kecuali jika negara tersebut dalam kondisi perang. Hanya organisasi sipil saja yang diperbolehkan memeriksa kapal-kapal lintas damai. Memang dalam hukum nasional, TNI AL berhak memeriksa kapal-kapal lintas damai di wilayah perairan Indonesia. Tetapi hal ini sangat bertentangan dengan hukum maritim internasional (UNCLOS, 1982) yang sudah disepakati oleh 168 negara termasuk Indonesia. Hal ini pula yang menyebabkan setiap kapal-kapal asing yang mau masuk ke perairan Indonesia selalu dikenakan biaya asuransi yang lebih tinggi dibanding dengan masuk ke perairan negara lainnya, yang menyebabkan lalulintas ekspor dan impor menjadi sangat mahal (karena biaya asuransi) jika masuk perairan Indonesia.Yang menjadi persoalan, manakala instansi itu selesai menjalankan tugasnya dan kapal akan bergerak kembali, ada instansi lain lagi yang menghentikan dan naik ke kapal tak lama kemudian. Persoalan akan menjadi rumit, manakala kapal yang dihentikan dan diperiksa itu adalah kapal berbendera asing.

Menurut praktek yang lazim di dunia pelayaran, kapal adalah the mobile state (negara yang berjalan) sehingga hanya tunduk kepada aturan hukum yang berlaku di negara berdasarkan benderanya. Jika ingin diproses dengan hukum negara lain, ada sejumlah aturan main yang juga berlaku internasional yang harus dipenuhi. Salah satunya melalui admiralty court/pengadilan. Mungkin inilah salah satu sebab, mengapa main line operator/MLO (pelayaran besar kelas dunia) enggan sandar di pelabuhan Indonesia. Hukum maritim internasional berlaku di wilayah perairan ZEE maupun di wilayah perairan teritorial bagi kapal-kapal lintas damai berbendera asing. Untuk kapal-kapal berbendera lokal tetap diserahkan kepada undang-undang yang sudah ada di negara setempat. Jika seorang pelaut tidak memenuhi persyaratan yang telah ditentukan jelas melanggar hukum maritim nasional maupun internasional. Dimana ketentuan dalam KUHP juga berlaku bagi kapal dan awaknya. Sebuah kapal berbendera Indonesia yang berada di perairan wilayah negara asing, apabila terjadi pelanggaran bea dan cukai serta peraturan kepelabuhan, dalam hal-hal dimana 
tersangkut orang-orang dalam pelayaran tersebut, juga berlaku ketentuan KUHP terhadapnya. Jelas dalam hal ini akan selalu menjurus pada lembaga penegak hukum seperti kepolisian, sebagai pelaksananya.

\section{ANALISIS}

\section{Implementasi Poros Maritim Dunia Menuju Masa Depan Indonesia}

Konsep implementasi semakin marak dibicarakan seiring dengan banyaknya pakar yang memberikan kontribusi pemikiran tentang implementasi kebijakan sebagai salah satu tahap dari proses kebijakan. Wahab dan beberapa penulis menempatkan tahap implementasi kebijakan pada posisi yang berbeda, namun pada prinsipnya setiap kebijakan publik selalu ditindaklanjuti dengan implementasi kebijakan. ${ }^{47}$ Daniel A. Mazmanian dan Paul A. Sabatier menjelaskan makna implementasi merupakan pelaksanaan keputusan kebijaksanaan dasar yang biasanya dalam bentuk undang-undang, namun dapat pula berbentuk perintah-perintah atau keputusan-keputusan eksekutif penting atau keputusan badan peradilan. Lazimnya, keputusan tersebut mengidentifikasikan masalah yang ingin diatasi, menyebutkan secara tegas tujuan atau sasaran yang ingin dicapai, dan berbagai cara untuk menstrukturkan atau mengatur proses implementasinya". ${ }^{48}$

Kebijakan poros maritim dunia sudah dituangkan dalam Peraturan Presiden Nomor 2 Tahun 2015 tentang Rencana Pembangunan Jangka Menengah Nasional (RPJMN) 2015-2019 dan juga dalam Peraturan Presiden Nomor 16 tahun 2017 tentang Kebijakan Kelautan Indonesia, bahwa Poros Maritim Dunia adalah suatu visi Indonesia untuk menjadi sebuah negara maritim yang berdaulat, maju, mandiri, kuat, serta mampu memberikan kontribusi positif bagi keamanan dan perdamaian kawasan dan dunia sesuai dengan kepentingan nasional (Pasal 1 angka 2).

Indonesia sudah merdeka selama 73 tahun, maka akan dilihat bagaimana implementasi poros maritIm dunia menuju masa depan Indonesia.

47 Akib, Haedar Dan Antonius Tarigan. 'Artikulasi Konsep Implementasi Kebijakan: Perspektif, Model Dan Kriteria Pengukurannya,' Jurnal Baca, Volume 1 Agustus 2008, Universitas Pepabari Makassar, 2008, Hlm 117.

48 Mazmanian, Daniel A and Paul A. Sabatier. Implementation and Public Policy, Scott Foresman and Company, USA, 1983, Hlm 139.
Bangsa ini sudah memiliki dua presiden yang berorientasi sekaligus berani menempatkan Indonesia sebagai negara pemain daripada sekadar negara penonton dalam konstelasi pergerakan politik dan pertahanan keamanan kawasan dan dunia. Kedua presiden tersebut adalah Soekarno dan Joko Widodo (Jokowi). Pembangunan maritim tidak bisa dilakukan serba instan. Untuk mengoptimalkan pembangunan maritim di tingkat nasional, regional dan global, dan khususnya dalam mencapai Poros Maritim Dunia dibutuhkan arah, orientasi, strategi dan antisipasi pembangunan yang efektif, konsisten dan berkelanjutan. Diperlukan berbagai upaya, keunggulan sumber daya, posisi strategis dan geopolitik yang perlu diarahkan untuk menjawab tantangan demi mewujudkan keunggulan Indonesia. Implikasi dari sebuah negara yang berkehendak menjadi aktor kelas kawasan, terlebih kelas dunia, adalah harus terwujudnya pembangunan kekuatan militer yang bersifat outward looking, yaitu kemampuan militer yang dipersiapkan untuk menghadang dan menghampiri ancaman serta lawan jauh melampaui batas terluar negara tersebut.

Pada era kepemimpinan Soekarno (19451966), Indonesia dikenal sebagai negara terkuat di bumi bagian selatan serta memiliki efek deterrence yang kuat dari sisi politik. Dengan anggaran pertahanan mencapai 29\% dari PDB, kekuatan militer kita memungkinkan kebijakan politik Soekarno terkait akan harga diri, kehormatan martabat, pertahanan dan keamanan bangsa, serta didukung oleh ketangguhan pasukan militer. Presiden Soekarno dan Jokowi sadar bahwa salah satu upaya agar negara mampu mengamankan jalur laut Nusantara dan sumber daya laut adalah memiliki kekuatan AL yang mampu menempati 12 lautan yang dimiliki negeri ini, menguasai titiktitik strategis penting pulau-pulau, choke points Malaka, dan 39 selat lainnya yang baik langsung ataupun tidak merupakan jalur utama pendukung kepentingan perdagangan, pergerakan sumber daya energi dan supply makanan (Sea Lanes of Trade/SLOT) serta merupakan jalur utama strategis militer (Sea Lanes of Communications/SLOC).

Tahun 2018 menandai dua pertiga implementasi kebijakan luar negeri pemerintahan Jokowi-JK yang dibingkai dalam Visi Misi Poros Maritim Dunia. Indonesia ingin dijadikan sebagai negara kepulauan dan bangsa maritim kuat, stabil dan sejahtera sehingga dapat memainkan peran 
signifikan di kancah regional Asia Pasifik dan Samudra Hindia (Indo-Pacific). Oleh karena itu, bagaimana Indonesia mampu mewujudkan poros maritim dunia mengimbangi ekspansi jalur sutra baru Tiongkok yang digagas oleh Xi Jin Ping. Rencana aksi poros maritim dunia mencakup lima agenda prioritas. Pertama, mempercepat upaya diplomasi penyelesaian konflik perbatasan, termasuk wilayah darat, dengan 10 negara tetangga; Kedua, melindungi teritori laut nasional (Kedaulatan NKRI); Ketiga, menjaga kekayaan sumber daya alam di dalam Zona Ekonomi Eksklusif (Diplomasi Ekonomi); Keempat, mengintensifkan diplomasi pertahanan (Diplomasi Maritim); Kelima, mendorong resolusi damai konflik internasional melibatkan negara-negara besar di kawasan Indo-Pasifik. Program aksi yang berdimensi kompleks, mulai dari hukum, politik, ekonomi, keamanan, hingga pertahanan. Diperlukan sebuah instrumen kerja diplomasi kreatif, aplikatif, dan efektif. Persoalan luar negeri selalu menjadi hirauan serius dimana terjadi eskalasi ketegangan antarnegara yang bersengketa di wilayah Laut Tiongkok Selatan. Eskalasi konflik dipicu oleh tindakan provokatif Beijing yang tidak menghiraukan Hukum Internasional, kedaulatan, dan kepentingan negara lain. Bahkan, pada Maret 2016 sempat terjadi insiden di perairan Natuna yang diklaim sebagai bagian wilayah kedaulatan Tiongkok (nine dash line). Tindakan responsif Jakarta hanya meliputi tiga komponen, yakni protes kepada Tiongkok yang telah melanggar yurisdiksi Indonesia; desakan agar Tiongkok mematuhi norma Hukum Internasional berdasarkan UNCLOS 1982; dan mengajak semua pihak yang berurusan dengan Tiongkok agar duduk bersama mencari solusi permanen. Hasilnya, Tiongkok menolak ajakan dialog secara multilateral dan tetap kukuh pada pendirian bahwa wilayah kedaulatan Tiongkok meliputi wilayah Natuna. Artinya, Indonesia belum berhasil mewujudkan agenda poros maritim di Laut Tiongkok Selatan. Kesemuanya menyimpan konsekuensi, baik potensial maupun aktual, terhadap implementasi agenda Poros Maritim Dunia Indonesia. Hingga kini belum terlihat bagaimana strategi yang dimiliki Indonesia dan telah dilaksanakan oleh jajaran diplomasi. Masyarakat mengerti bahwa banyak hal terkait diplomasi tidak bisa disampaikan secara terbuka, diliput media, dan dijelaskan dengan terperinci karena menyangkut aspek kerahasiaan negara serta implikasi taktis. Setidaknya terdapat tanda-tanda perubahan cara pandang dan penerapan kebijakan yang dapat diamati sebagai perwujudan agenda poros maritim dunia. Disamping itu implementasi kebijakan poros maritim dunia ditengarai akan lebih efektif jika didasari oleh riset. Riset tersebut antara lain terkait dengan alur laut dan potensi sumber daya laut.

Implementasi kebijakan Poros Maritim Dunia Pemerintahan Joko Widodo mengundang sikap reaktif dari negara-negara didalam dan luar kawasan Asia Tenggara yang memperlihatkan sikap yang tidak mendukung atau menentang apa yang dijalankan secara sepihak oleh Pemerintahan Joko Widodo ${ }^{49}$ Sikap ini tentu saja dapat mempengaruhi keharmonisan dan stabilitas keamanan yang selama ini dalam kondisi relatif kondusif di kawasan. Reaksi yang cenderung resisten, yang ditunjukkan secara terbuka, dan mengandung pesan pembalasan (aksi retaliasi) dapat mempengaruhi interaksi antar-negara di kawasan. Demikian juga dari sisi domestik menunjukkan bahwa maritim hanya menjadi perhatian Kementerian Kelautan dan Perikanan. Sementara kementerian/lembaga/ badan lainnya masih mengabaikan perhatian pada sektor maritim. Pandangan sempit pada aspek maritim tersebut menunjukkan kebenaran atas ucapan Hasjim Djalal yang menyatakan bahwa banyak negara kepulauan namun bukan negara maritim. Negara maritim ditunjukkan dengan pemanfaatan dan pengelolaan maritim belum terwujud dalam sinergitas antar lembaga. Hal ini menunjukkan bahwa kebijakan tidak terimplementasikan (non-implementation) dan adanya kementerian/badan/lembaga yang tidak berhasil menjalankannya (unsuccessful) karena eksekusinya yang jelek (bad execution). Kebijakan non implementation menurut Hogwood dan Gunn terjadi karena pihak yang terlibat dalam pelaksanaannya tidak mau bekerja sama atau telah bekerja sama secara tidak efisien, bekerja setengah hati atau karena tidak sepenuhnya menguasai permasalahan, atau permasalahan yang diselesaikan diluar jangkauan kekuasaannya. Unsuccesfull implementation atau implementasi yang tidak berhasil biasanya terjadi manakala suatu kebijakan telah dilaksanakan sesuai dengan rencana namun mengingat kondisi eksternal ternyata tidak menguntungkan, kebijakan tersebut tidak berhasil dalam mewujudkan dampak atau

\footnotetext{
49 Poltak Partogi. 2015. “Kebijakan Poros Maritim Dunia Joko Widodo dan Implikasi Internasionalnya". Politica. Vol. 6 No. 2. Agustus. Nainggolan, 2015 hlm 169.
} 
hasil akhir yang dikehendaki. ${ }^{50}$ Kebijakan poros maritim merupakan proyek raksasa yang boleh dikatakan proyek mercusuar yang melibatkan banyak pihak seperti, kementerian/badan/lembaga/TNI/Polri yang semuanya memiliki kepentingan atas kebijakan tersebut. Siapa yang menjadi leading sektor dari proyek poros maritim? Seperti yang dijelaskan oleh Grindle bahwa implementasi kebijakan publik sesungguhnya bukanlah sekedar bersangkut paut dengan mekanisme penjabaran keputusankeputusan politik kedalam prosedur-prosedur rutin lewat saluran-saluran birokrasi. ${ }^{51}$ Melainkan lebih dari itu, ia menyangkut masalah konflik, keputusan dan siapa yang memperoleh apa dari satu kebijakan. Kebijakan poros maritim yang belum terimplementasi disebabkan karena: 1) perumusan kebijakan yang merupakan tahapan penting namun sering disepelekan tanpa mempertajam perumusan masalah kebijakan dengan mencari cara dan strategi yang tepat dalam mencapai tujuan kebijakan: 2) isi atau konten kebijakan. Kebijakan dari sisi konten setidaknya memiliki sifat-sifat sebagai berikut : jelas, tidak distorsi, didukung oleh teori yang teruji, mudah dikomunikasikan ke kelompok target, didukung sumberdaya baik manusia maupun finansial yang baik; 3) implementator harus memiliki kapabilitas, kompetensi, komitmen, dan konsistensi dalam melaksanakan sebuah kebijakan; 4) Lingkungan. Keadaan sosial ekonomi, politik, dukungan publik maupun kultur populasi dimana kebijakan dilaksanakan.

Namun demikian pemerintah dalam implementasinya terhadap poros maritim dunia telah membuat langkah-langkah strategis diantaranya melakukan gerakan penanggulangan perikanan ilegal telah berhasil dan ini sudah diakui dunia internasional; menurunkan dwalling time dari 6,33 hari; terjadi penambahan trayek angkutan laut perintis dari 84 menjadi 96; penurunan harga sejumlah komoditas, khususnya di wilayah timur karena perbaikan konektivitas di laut. Oleh karena itu poros maritim dunia Indonesia yang akan datang adalah perlu memformulasikan konsep poros maritim dunia sebagai proses sekaligus hasil. Artinya, perlu gambaran yang jelas dan terukur

50 Aksara Wahab, “Analisis Kebijakan Dari Formulasi Ke Implementasi Kebijakan Negara. Jakarta: PT. Bumi Aksara. (2015)

51 Merilee S. Grindle, "Politics and Policy Implementation in the Third World, (New Jersey: Princeton University Press, 1980), Hlm. 1.). tentang karakteristik poros maritim dan dapat dikomunikasikan kepada publik dengan baik. Poros maritim dunia bukanlah proyek jangka panjang yang matang serta rumusan peta jalan yang sistematis dengan target-target tahunan yang terukur sehingga dapat tergambar kapan pencapaian itu bisa terwujud. Karena poros maritim dunia untuk jangka panjang perlu dibuat dasar hukum poros maritim dunia sehingga bisa mengikat dan tidak mudah berubah ketika terjadi pergantian rezim pemerintahan, artinya dasar hukum poros maritim dunia Indonesia adalah Undang-Undang yang terintegrasi dalam Rencana Pembangunan Jangka Panjang. Apabila dasar hukum hanya peraturan presiden (perpres), maka sangat rentang terhadap perubahan rezim. Selanjutnya urusan kemaritiman lebih luas dari tupoksi Kemenko Kemaritiman yang hanya membawahi empat kementerian, artinya poros maritim dunia bukan sekedar tanggung jawab menko kemaritiman melainkan juga semua anggota kabinet ataupun Lembaga Pemerintahan Non Kementerian (LPKN) sehingga perlu pemetaan peran tiap lembaga dan tercermin dalam profil penganggaran. Kemudian penguatan pilar poros maritim dunia Indonesia melalui sumber daya manusia dan ilmu pengetahuan serta teknologi. Karena dengan demikian langkah sistematisnya bisa dilakukan melalui pendidikan dengan perubahan kurikulum. Sehingga kemaritiman bisa hadir dalam pikiran masyarakat dan mengembalikan kesadaran kita tentang kemaritiman.

\section{KESIMPULAN}

Indonesia sudah merdeka selama 73 tahun, maka akan dilihat bagaimana implementasi poros maritim dunia menuju masa depan Indonesia. Bangsa ini sudah memiliki dua presiden yang berorientasi sekaligus berani menempatkan Indonesia sebagai negara pemain daripada sekadar negara penonton dalam konstelasi pergerakan politik dan pertahanan keamanan kawasan dan dunia. Kedua presiden tersebut adalah Soekarno dan Joko Widodo (Jokowi). Indonesia sebagai negara kepulauan dan bangsa maritim yang kuat. Dari pertanyaan pertama terlihat, Poros maritim dunia merupakan sebuah gagasan strategis yang diwujudkan untuk menjamin konektifitas antar pulau, pengembangan industri perkapalan dan perikanan, perbaikan transportasi laut serta fokus pada keamanan maritim. Berbagai kemunculan poros maririm dunia, baik poros maritim klasik 
maupun poros maritim modern. Keberlangsungan poros maritim Nusantara hingga masa modern dibandingkan poros maritim lain di dunia menunjukkan bahwa kawasan Asia Tenggara merupakan kawasan yang sangat strategis dan berperan dalam menentukan kegiatan pelayaran dan perdagangan dunia. Untuk mengoptimalkan pembangunan maritim di tingkat nasional, regional dan global, dan khususnya dalam mencapai Poros Maritim Dunia dibutuhkan arah, orientasi, strategi dan antisipasi pembangunan yang efektif, konsisten dan berkelanjutan. Hal ini sudah dilalui selama empat tahun pemerintahan Joko WidodoJusuf Kalla melalui visi dan misi serta nawacitanya. Kebijakan poros maritim pada visi dan misi Presiden menunjukkan orientasi kebijakan luar negeri Jokowi pada geopolitik maritim. Presiden Joko Widodo memaparkan citacita Indonesia menjadi Poros Maritim Dunia, citacita dan agenda tersebut menjadi fokus Indonesia di abad ke-21 sehingga Indonesia akan menjadi Poros Maritim Dunia. Indonesia mampu memanfaatkan posisi strategis dalam kemaritiman dunia hingga saat ini. Dikaitkan dengan pertanyaan kedua dalam implementasinya terlihat bahwa kebijakan Poros Maritim Dunia Pemerintah Joko Widodo tetap dijalankan untuk mewujudkan Indonesia menjadi poros maritim dunia, dimana didalam implementasinya sudah terlihat adanya gerakan penanggulangan perikanan ilegal telah berhasil dan ini sudah diakui dunia internasional, menurunkan dwalling time, penambahan trayek angkutan laut perintis, dan penurunan harga sejumlah komoditas.

\section{SARAN}

Untuk membangun Indonesia sebagai negara maritim melalui poros maritimnya, perlu menggarap gagasan poros maritim dunia. Untuk mengoptimalkan pembangunan maritim di tingkat nasional, regional dan global, dan khususnya dalam mencapai poros maritim dunia dibutuhkan arah, orientasi, strategi dan antisipasi pembangunan yang efektif, konsisten dan berkelanjutan. Diperlukan berbagai upaya, keunggulan sumber daya, posisi strategis dan geopolitik yang perlu diarahkan untuk menjawab tantangan demi mewujudkan keunggulan Indonesia. Disamping itu diperlukan juga memformulasikan konsep poros maritim dunia sebagai proses sekaligus hasil. Perlu dibuat dasar hukum poros maritim dunia sehingga bisa mengikat dan tidak mudah berubah ketika terjadi pergantian rezim pemerintahan dalam bentuk undang-undang.

\section{UCAPAN TERIMA KASIH}

Terimakasih saya ucapkan kepada pihak-pihak yang memberi bantuan terutama kepada reviwer yang membantu dalam penulisan artikel ini.

\section{DAFTAR KEPUSTAKAAN}

Bulliet. "R.W., Crossley, P.K., Headrick, D.R., Hirsch, S.W., Johnson, L.L., Northrup, D. The Earth and Its People, 4th Edition, Boston:Cengange Learning, hlm. G-8.

Cocker 2007, B.F. Christianity and Greek Philosophy, Blackmask.

Djalal, Hasjim. "Singapura Sudah Menjadi Negara Maritim, Indonesia Belum. Diakses Melalui http://Lan.Go.Id/Id/Berita-Lan/Hasjim-

Djalal-Singapura-Sudah-Menjadi-Negara-

Maritim-Indonesia-Belum Pada Hari Selasa

Tanggal 14 Mei 2019 Jam 10.05 WIB

Grindle, Merilee S. "Politics and Policy Implementation in the Third World, (New Jersey: Princeton University Press, 1980), hlm. 1.

Blogspot.Com/2017/08/Pengertian-Poros-

Maritim.html, Diakses Pada Hari Jumat

Tanggal 15 Maret 2019 Jam 14.05 WIB.

Junef, Muhar. "PENEGAKAN HUKUM DALAM RANGKA PENATAAN RUANG GUNA MEWUJUDKAN PEMBANGUNAN BERKELANJUTAN." Penelitian Hukum De Jure 17, no. 4 (2017): 379-391.

Kadar. A, 2015. "Pengelolaan Kemaritiman Menuju Indonesia sebagai Poros Maritim Dunia." Peneliti di Lembaga Concern (Consultancy and Research). Jurnal Keamanan Nasional Vol. I, No. 3.

Kawilarang. Renne R.A, "Warisan Besar Menlu Hassan Wirajuda," dalam http://www.viva.co.id/berita/dunia/98969warisan-besar-menlu-hassan-wirajuda 2009.

Kompas, Rabu 9 November 2017 (4). Masih Terjadi Tumpang Tindih Kebijakan.

Laksmana. Evan A., Iis Gindarsah, and Andrew W. Mantong. 2014. Menerjemahkan Visi Poros Maritim Global ke Dalam kerangka Diplomasi Pertahanan Maritim Dalam Kebijakan Luar Negeri Indonesia di Era 
Jokowi 2018. Centre for Strategic and International Studies, Jakarta.

Limbong. Bernhard. 2015.Poros Maritim. Pustaka Margareta, Jakarta.

Lopez, E., Piquero, S. Was the Little Divergence so Big? Spanish Real Wages in the North Western European Mirror, 1500-1800. Pamplona-Iruna, 3(4), 2013, 1-30, hal. 11. Ketiga, poros maritim Persia yang menghubungkan Timur Tengah, Afrika, dan India (Wills, hal. 93.).

Moleong, Lexy J. 2007 : 6. Metodologi Penelitian Kualitatif. Bandung: PT. Remadja Rosdakarya.

Mamuji, Soerjono Sukanto dan Sri. "Penelitian Hukum Normatif: Suatu Tinjauan Singkat, Jakarta, Rajawali, Press, 1985, 13-14

Manurung, Hendra. "Menuju Poros Maritim Dunia: Masa Depan Indonesia Https://Www.Researchgate.Net/Publication/ 323369195 Diakses hari Selasa 19 Maret 2019 Jam 8.41 WIB (2018).

Muahamad. Victor Simela. 2014. Indonesia Menuju Poros Maritim Dunia, "Info Singkat Hubungan Internasional, Vol. VI, No. 21, (November 2014).

Nainggolan, Poltak Partogi. 2015. "Kebijakan Poros Maritim Dunia Joko Widodo dan Implikasi Internasionalnya". Politica. Vol. 6 No. 2. Agustus.

Nikmah, Masykurotun. "Pengembangan Materi Ajar Posisi Strategis Indonesia Sebagai Poros Maritim Dunia Pada Siswa Kelas XI." Uniersitas Negeri Surabaya 1, no. 1 (2017): 92-98.

Prasetia, Ade. "Menuju Indonesia Sebagai Poros Maritim Dunia 'Kajian Strategis Perulangan Kebesaran Bangsa Melalui Optimalitas Geostrategis Nusantara ' Jurnal Maritim Indonesia Juni 2015 Edisi-3.Diakses Melalui Https://Docplayer.Info/80423941-IndonesiaSeb".

Rodrigue, J-P. "Ports and Maritime Trade. Dalam The Encyclopedia of Geography, Warf, B (Ed), London: Sage, hal. 4.

Roos, G.M. “2008, hlm. 34

Safril Hidayat dan Ridwan. "Kebijakan Poros Maritim Dan Keamanan Nasional Indonesia: Tantangan Dan Harapan." Jurnal Pertahanan \& Bela Negara 7, no. 3 (2017): 108-121.
Shekar. Vibhanshu dan Joseph Chinyong Liow 2014, "Indonesia as a Maritime Power: Jokowi's Vision, Strategies, and Obstacles Ahead," Brookings, 7 November 2014, Https://www.brookings.edu/articles/indonesi a-as-a-maritime-power-jokowis-visionstrategies-andobstacles-ahead/.

Subandono Diposaptono. "Membangun Poros Maritim Dunia Dalam Perspektif Tata Ruang Laut. Cetakan Ke 3 Kementerian Kelautan Dan Perikanan.(2017): 42

Sukma. Rizal. 2009, "Indonesia Needs a PostASEAN Foreign Policy," The Jakarta Post, 30 Juni 2009, http://www.thejakartapost.com/news/2009/0 6/30/indonesia-needs-a-postasean-foreignpolicy. html.

Wahab, Aksara. "Analisis Kebijakan Dari Formulasi Ke Implementasi Kebijakan Negara. Jakarta : PT. Bumi Aksara. (2015)

Yudhoyono, Susilo Bambang. "Geopolitik Kawasan Asia Tenggara: Perspektif Maritim. Http://Jakartagreater.Com/ Geopolitik-Kawasan-Asiatenggara/. Diakses Pada Tanggal 12 Maret 2019 Pukul 10.10 WIB.

Akib, Haedar Dan Antonius Tarigan. 'Artikulasi Konsep Implementasi Kebijakan: Perspektif, Model Dan Kriteria Pengukurannya,' Jurnal Baca, Volume 1 Agustus 2008, Universitas Pepabari Makassar, 2008, Hlm 117.

Http://Bisniskeuangan.Kompas.Com/Read/2014/10 /21/203422926/

Visi.Maritim.Jokowi.Tantangan.Bernilai.Rib uan.Triliun.Rupiah.

Http://Blogspot.Com/2017/02/Penyebab-KenapaIndonesia-Disebut.Html Diakses Pada Hari Senin 11 Maret 2019).

Http://M.Liputan6.Com/Bisnis/Read/2138321/Mel ongok-Tol-Laut-Jokowi-Modal-Ri-JadiPoros-Maritim-Dunia), Diakses Pada Hari Selasa Tanggal 14 Mei 2019 Jam 13.12 WIB.

Mazmanian, Daniel A and Paul A. Sabatier. Implementation and Public Policy, Scott Foresman and Company, USA, 1983, Hlm 139.

Allan Westcoot, (Ed). Mahan on Naval Warfare, Selections from the Writing of Rear Admiral Alfred T. Mahan, (Mineola, New York: Dover Publications, 1985. 
BBC.Com.

http://www.BBC.Com/Indonesia/Berita Indonesia/2014/06/140622_indonesia_ debatcapres_dua.

Http://Bisniskeuangan.Kompas.Com/Read/2014/10 /21/203422926/

Visi.Maritim.Jokowi.Tantangan.Bernilai.Rib uan.Triliun.Rupiah.

Http://Jurnalmaritim.Com/2014/08/Indonesia-

Poros-Maritim-Dunia-Menuju-EkonomiBerbasis-Kelautan/.

Https://Www.Gatra.Com/Rubrik/Info-Dpr/316965Indonesia-Sebagai-Poros-Kemaritiman-

Dunia Diakses Pada Hari Kamis, Tanggal 16 Mei 2019, Jam 10. 44 WIB.

Indonesia Sebagai Poros Maritim Dikases Melalui : http://www.Bppk.Kemenkeu.go.id/id/publik asi/artikel/150-artikel-keuanganumum/20555-Poros-Maritim-DanPerkembangan-Perekonomian-Indonesia.)

Kompas. Minggu 4 Maret 2018 (2). Riset Titik Awal Mewujudkan Poros Mariti Dunia.

Peraturan Menteri Perhubungan Nomor 68 Tahun 2011 Tentang Alur Pelayaran Di Laut.

Peraturan Presiden Republik Indonesia Nomor 16 Tahun 2017 Tentang Kebijakan Kelautan Indonesia Pasal 1 Angka 1. 